\title{
Teori Interaksionisme Simbolik dalam Kajian Ilmu Perpustakaan dan Informasi ${ }^{1}$
}

\author{
Laksmi \\ laksmi@ui.ac.id
}

\begin{abstract}
Abstrak
Teori interksionisme simbolik (symbolic interactionism), merupakan salah satu teori dalam pendekatan kualitatif yang dianggap sesuai untuk menganalisis fenomena di bidang ilmu perpustakaan dan informasi. Inti kajian ilmu perpustakaan dan informasi yang mendasar adalah bagaimana para profesional informasi khususnya dan masyarakat pada umumnya melakukan tindakan terhadap pengetahuan atau informasi. Pakar yang pertama kali memperkenalkan teori interaksionisme simbolik adalah Jesse Shera. Teori interaksi simbolik berangkat dari pemikiran bahwa realitas sosial merupakan sebuah proses yang dikonstruksi secara dinamis, dan didasari oleh tiga premis Herbert Blumer. Lembaga informasi, seperti perpustakaan, pusat informasi, pusat arsip, dan museum merupakan tempat pengelolaan pengetahuan. Perpustakaan, lembaga yang paling dekat dengan masyarakat, merupakan sebuah panggung di mana simbol-simbol ilmu pengetahuan dipentaskan. Sebagai pengelola pengetahuan, profesional informasi memainkan peran strategis, terutama dalam membangun masyarakat pembelajar, yang menjadi fondasi bagi terbentuknya masyarakat informasi. Sayangnya, kondisi lembaga informasi dikelola oleh profesional informasi dengan citra diri yang tampak buruk; dan gaya hidup masyarakat yang cenderung hedonis dan konsumtif, serta berbudaya visual. Dapat disimpulkan bahwa teori dan metode interaksionisme simbolik di bidang ilmu perpustakaan dan informasi perlu dikembangkan lebih jauh. Pengetahuan di masa lalu menjadi makna yang berarti bagi status seseorang, di masa sekarang, menjadi modal intelektual atau modal budaya bagi relasi kuasa di segala aspek kehidupan. Di masa globalisasi ini, di mana interaksi antar individu semakin intens dan semakin bersifat virtual, simbol-simbol pengetahuan yang digunakan juga semakin variatif.
\end{abstract}

Keywords: library and information sciene, library research, symbolic interactionism, Herbert Blumer, Jesse Shera,

${ }^{1}$ Makalah ini dipresentasikan pada Seminar Nasional Peranan Teori Ilmu Sosial dalam Pengembangan Ilmu Informasi dan Ilmu Perpustakaan, di UNAIR, Kamis, 20 Oktober 2016. 


\section{Latar Belakang}

Teori interksionisme simbolik (symbolic interactionism), yang diperkenalkan oleh Herbert Blumer dan George Herbert Mead tahun (1863 - 1931), sudah lama dikenal dalam kajian ilmu perpustakaan dan informasi. Teori tersebut merupakan salah satu teori dalam pendekatan kualitatif yang dianggap sesuai dalam menganalisis fenomena di bidang ilmu perpustakaan dan informasi. Berdasarkan analisis para pakar, payung di bidang ini adalah pengetahuan atau informasi (Chowdhury, et.al., 2008; Stueart \& Moran, 2007). Inti kajian ilmu perpustakaan dan informasi yang mendasar adalah bagaimana para profesional informasi khususnya dan masyarakat pada umumnya melakukan tindakan terhadap pengetahuan atau informasi. Frasa melakukan tindakan terhadap informasi mencakup semua aspek yang terdapat dalam kajian bidang ini, yaitu misalnya mengorganisir pengetahuan atau informasi (mulai dari mengklasifikasi, menentukan tajuk subjek, hingga mencetaknya ke dalam bentuk katalog), pelayanan atau diseminasi informasi, pencarian informasi, representasi informasi, plagiarisme, perlindungan hak cipta, pengelolaan pengetahuan, berbagai pengetahuan, dan sebagainya.

Di dalam kajian bidang ilmu perpustakaan dan informasi, pakar yang pertama kali memperkenalkan teori interaksionisme simbolik adalah Jesse Shera (Bivens-Tatum, 2013). Menurutnya, kepustakawanan adalah pengalihan pengetahuan, di mana diri (self) di dalam situasi tertentu menjadi penting dalam menentukan substansi pengetahuan. Diri harus mampu menginterpretasi dan memahami diri orang lain, melalui simbol, agar dapat mencapai kesepakatan dalam mengelola pengetahuan. Dalam kajian ilmu perpustakaan dan informasi, diri merupakan bagian dari lembaga informasi yang terdiri dari profesional informasi, yang mencakup pustakawan, arsiparis, petugas museum, serta masyarakat informasi yang mencakup pengguna, masyarakat, pemerhati, pemerintah, dan kelompok usaha yang dianggap pesaing seperti mal, bioskop, kafe, toko buku, dan sebagainya.

Pengalihan pengetahuan tersebut terjadi pada interaksi individu atau masyarakat terhadap pengetahuan, yang muncul dalam tema manajemen 
pengetahuan, mulai dari penciptaan, pengolahan, penyimpanan, penyebaran atau berbagai pengetahuan, perilaku informasi, masyarakat informasi, masyarakat virtual, masyarakat jaringan, budaya informasi atau budaya pengetahuan. Pemikiran interaksionisme simbolik menekankan proses interaksi yang dilakukan oleh berbagai komunitas di dalam berbagai aktivitas di atas dalam kaitannya dengan pengetahuan yang berlangsung secara dinamis dan unik dengan menggunakan simbol-simbol tertentu.

Kepustakawanan yang merupakan pengalihan pengetahuan mengaitkan simbol dalam tindakan-tindakan manusia terhadap pengetahuan (Veinot \& Williams, 2012). Simbol muncul bukan hanya berbentuk bahasa verbal, tetapi juga bahasa non-verbal, serta berbagai atribut simbolik lainnya (Budd, 2003). Selain itu, manusia tidak dapat mengelak dari campur-tangan teknologi (Chowdhury, et.al, 2008, p. 6). Teknologi menjadi jalan yang paling umum bagi pengalihan pengetahuan, termasuk ideologi-ideologi tertentu, seperti kapitalisme, sehingga mengubah gaya hidup masyarakat. Realitas pengetahuan bukan hanya sebagai produk budaya, yang merupakan kebutuhan sehari-hari yang dimiliki, dimanfaatkan, dan dimanipulasi oleh individu atau kelompok masyarakat, tetapi juga merupakan hasil interaksi dengan teknologi. Kekuatan besar yang dimunculkan oleh teknologi ini adalah adanya globalisasi (Abdullah, 2006, p. 165). Globalisasi memaksa masyarakat untuk menciptakan strategi bertahan hidup dan strategi pengumpulan kekayaan, yang membawa pasar menjadi kekuatan dominan dalam pembentukan nilai dan tatanan sosial yang bertumpu pada kepemilikan pengetahuan.

Pemikiran tersebut menjadi dasar bagi kajian ilmu perpustakaan dan informasi untuk menggunakan kajian interaksionisme simbolik (Laksmi, 2012; Pendit, 2009). Kajian simbolik yang menekankan proses kognitif dan simbolik dari pengamat maupun yang diamati akan meningkatkan pemahaman yang lebih tajam dalam perilaku manusia (Saifuddin, 2005, p. 294). Kajian ini menghubungkan simbol dan tanda dengan tindakan dan konteks sosial untuk menemukan sistem simbol dalam pengalihan pengetahuan. Oleh karena itu, rumusan pertanyaan dari penjelasan di atas adalah bagaimana individu-individu yang terlibat dalam tindakan terhadap 
pengetahuan tersebut mempraktikkan dan memaknai aktivitas mereka tersebut? Rumusan tersebut mencakup berbagai gejala yang timbul di dalam proses pengalihan pengetahuan, berdasarkan penggunaan simbol, di dalam berbagai konteks sosial.

\section{Uraian Ringkas Teori Interaksi Simbolik}

Teori interaksi simbolik berangkat dari pemikiran bahwa realitas sosial merupakan sebuah proses yang dinamis. Individu-individu berinteraksi melalui simbol, yang maknanya dihasilkan dari proses negosiasi yang terusmenerus oleh mereka yang terlibat dengan kepentingan masing-masing (Abdullah, 2006, p. 5). Makna suatu simbol bersifat dinamis dan variatif, tergantung pada perkembangan dan kepentingan individu, yang dibingkai oleh ruang dan waktu. Seperti yang telah disebutkan sebelumnya, individu diletakkan sebagai pelaku aktif, sehingga konsep mengenai diri (self) menjadi penting. Konsep diri yang dikaitkan dengan emosi, nilai, keyakinan, dan kebiasaan-kebiasaan, serta pertimbangan masa lalu dan masa depan, turut mempengaruhi diri dalam pengambilan peran.

Namun demikian, diri tidak terisolasi, sebab ia bertindak dalam kelompok individu. Diri tidak dapat memaknai suatu simbol tanpa adanya individu lain yang berperan sebagai cermin untuk melihat diri sendiri (Arrianie, 2008, p. 35). Dalam kehidupan sosial, manusia menggunakan simbol untuk mempresentasikan maksud mereka, demikian juga sebaliknya. Proses penafsiran atas simbol-simbol ini terhadap perilaku pihak-pihak yang terlibat dalam interaksi sosial pada dasarnya adalah produk dari interpretasi mereka atas dunia di sekeliling mereka. Individu memilih perilaku sebagai hal yang layak dilakukan, berdasarkan cara individu mendefinisikan situasi yang ada. Makna muncul karena ada interaksi antar individu, yang muncul dari hasil interpretasi pikiran manusia mengenai diri, serta hubungannya di dalam masyarakat. Pemahaman terhadap simbol harus dipahami bahwa simbol adalah objek sosial yang muncul dari hasil kesepakatan bersama dari individu-individu yang menggunakannya. Individu-individu tersebut memberi arti, menciptakan, dan mengubah objek di dalam interaksi. Simbol 
sosial tersebut dapat mewujud dalam bentuk objek fisik, bahasa, serta tindakan.

Dalam interaksi manusia dengan menggunakan simbol, manusia menginterpretasi situasi dengan pikiran (mind). Pikiran manusia melibatkan kegiatan mental di dalamnya. Manusia menggunakan pikiran untuk dapat menempatkan diri di dalam posisi orang lain dan kemampuan menggunakan simbol yang mempunyai makna sosial yang sama, sehingga manusia mampu menafsirkan arti dari suatu pikiran dengan tepat. Kemampuan tersebut diekspresikan melalui bahasa, baik bahasa verbal maupun non-verbal, yang disebut sebagai simbol. Serupa dengan pikiran manusia, diri (self) juga merupakan suatu proses sadar yang memiliki beberapa kemampuan yang terus berkembang melalui interaksi dengan individu lain.

Perkembangan tersebut dilakukan melalui proses sosialisasi, mulai dari masa kanak-kanak hingga menjadi dewasa. Proses tersebut memungkinkan individu memiliki kemampuan untuk melihat dirinya sebagaimana ia melihat obyek yang berada di luar dirinya. Konsep tersebut disebut sebagai looking-glass self. Artinya, diri individu bisa membayangkan bagaimana ia seharusnya tampil di hadapan orang lain; ia juga dapat membayangkan bagaimana penilaian orang lain terhadap penampilannya; dan ia dapat mengembangkan perasaan tertentu sebagai akibat dari bayangan diri individu terhadap perasaan oran lain. Diri di antara individu-individu lain berinteraksi dalam suatu kelompok masyarakat, menciptakan simbol. Dalam kehidupan sosial, simbol-simbol tersebut diciptakan, digunakan, dan dimaknai berdasarkan kesepakatan bersama. Simbol yang dimaknai secara bersama-sama, menjadi dasar yang kuat dalam proses menciptakan dan mengkonstruksikan hubungan sosial oleh setiap individu di tengah masyarakat, di mana setiap individu terlibat dalam perilaku yang mereka pilih secara aktif. Tindakan individu tersebut mengantarkannya dalam proses pengambilan peran di tengah masyarakat.

Pemikiran interaksionisme simbolik didasari oleh tiga premis Herbert Blumer yang menyatakan bahwa, premis pertama, manusia bertindak terhadap sesuatu atas dasar makna yang dimiliki benda-benda itu bagi 
mereka. Dengan kata lain, manusia dianggap aktif dalam menentukan dan memaknai lingkungan atau situasi. Premis kedua, makna-makna tersebut merupakan hasil interaksi sosial yang terus-menerus dan terjadi berulangulang dalam suatu masyarakat. Makna pada suatu tanda, yaitu objek, peristiwa, atau gagasan tidak melekat pada tanda tersebut, tetapi merupakan hasil dari negosiasi. Premis ketiga, makna-makna tersebut diperbaharui melalui suatu proses penafsiran yang digunakan oleh setiap individu dalam keterlibatannya dengan objek yang dihadapinya. Berdasarkan premis tersebut, maka makna dapat berubah sesuai dengan konteks dalam ruang dan waktu yang membingkai interaksi.

Teori interaksi simbolik memiliki perspektif teoritik yang cenderung menekankan perilaku manusia dalam masyarakat atau kelompok, pada pola-pola dinamis dari tindakan sosial, dan hubungan sosial. Hubungan dan struktur sosial dikonseptualisasikan secara lebih kompleks, lebih tak terduga, dan aktif. Di sisi ini masyarakat terdiri dari individu-individu yang berinteraksi yang tidak hanya bereaksi, namun juga menangkap, menginterpretasi, bertindak, dan mencipta. Perspektif teoritik tersebut melahirkan pendekatan dramaturgis dari Erving Goffman (1922- 1982), etnometodologi dari Harold Garfinkel, dan fenomenologi. Orientasi metodologi dalam teori interaksionisme simbolik adalah interaksi manusia yang saling menginterpretasikan tindakan masing-masing melalui penggunaan simbol-simbol untuk memperoleh pemahaman makna. Interaksionisme simbolik pada intinya menjelaskan tentang metode individu yang dilihat bersama dengan orang lain, menciptakan sistem simbolik dan bagaimana cara dunia membentuk perilaku manusia.

Dalam kehidupan sehari-hari, manusia membutuhkan pengetahuan untuk menghadapi seluruh permasalahan di dunia yang bersifat dinamis, penuh ketidakpastian dan selalu berubah (Case, 2002, p. 8). Untuk mengatasinya, manusia baik secara individu maupun kelompok, menjadikan sistem pengetahuan sebagai pedoman dan pengarah dalam bertindak dan berperilaku (Clifford Geertz). Di bidang ilmu perpustakaan dan informasi, gagasan atau konsep tersebut setara dengan pengetahuan dan diwujudkan ke 
dalam perilaku simbolis dan juga dalam bentuk simbol berupa karya, baik fiksi maupun non-fiksi (Case, 2002, p. 43; Gorman \& Clayton, 2005, p. 5).

Kajian ilmu perpustakaan dan informasi merangkumnya ke dalam budaya pengetahuan atau budaya informasi. Budaya pengetahuan tersebut dimanifestasikan ke dalam tataran sosial dan tataran karya. Dalam tataran sosial, manifestasinya berupa perilaku terhadap pengetahuan, yaitu mencakup perilaku pencarian informasi, literasi informasi, layanan oleh pustakawan kepada pemustaka atau pengguna, adaptasi manusia dengan teknologi, perpustakaan membangun budaya populer, dan masih banyak lagi (Case, 2002, p. 138-140). Lembaga informasi sebagai ruang sosial tidak terlepas dari adanya tarik-menarik kepentingan oleh sekelompok orang, pertentangan nilai, resistensi, maupun negosiasi atau kesepakatan (Laksmi \& Wijayanti, 2012, p. 117). Dalam tataran karya, manifestasinya berupa karya fiksi seperti novel dan film, maupun non-fiksi seperti teks DDC, teks undang-undang, lembaran surat, dan sebagainya. Karya fiksi merupakan manifestasi konsep manusia dalam bentuk narasi fiktif, yaitu suatu imajinasi dengan tokoh dan rangkaian peristiwa yang merupakan representasi dari kehidupan nyata yang dirangkai ke dalam sebuah plot yang kompleks (Hall, 2013, p. 173; Leckie, et al (eds.), 2010, p. 306).

\section{Penerapan teori interaksionisme simbolik pada IP\&I}

Lembaga informasi, seperti perpustakaan, pusat informasi, pusat arsip, dan museum merupakan tempat pengelolaan pengetahuan. Perpustakaan, lembaga yang paling dekat dengan masyarakat, merupakan sebuah panggung di mana simbol-simbol ilmu pengetahuan dipentaskan. Ruang perpustakaan dengan atributnya, berupa rak buku, meja, kursi, dan koleksi bahan pustaka, dimaknai sebagai tempat individu menyerap pengetahuan di ruang sakral yang sunyi. Ketika seseorang memasuki ruangan tersebut, secara spontan ia akan mengatur sikapnya untuk tidak berisik. Sebagian lain masyarakat memaknai kesunyian dan suasana tenang di ruang perpustakaan sebagai simbol suasana mistis, yang dapat menimbulkan rasa takut. Suhu lembab dari dinding dan buku yang berdebu menambah suasana seram di perpustakaan, 
sekaligus ancaman penyakit.

Banyak yang datang ke perpustakaan bukan sekedar untuk menimba pengetahuan, tetapi sekaligus untuk memenuhi kepentingan lainnya, seperti menemui kekasih, mencari tempat yang nyaman untuk beristirahat, mencari ketenangan, dan sebagainya. Membuat janji bertemu dengan kekasih di perpustakaan dapat dimaknai bahwa ia ingin menarik perhatian kekasihnya yang merupakan anak seorang guru, dengan cara menunjukkan bahwa dirinya adalah seorang intelektual. Di abad pencerahan ketika teknologi mulai diciptakan dan mulai muncul kesadaran akan pentingnya ilmu pengetahuan, perpustakaan bukan hanya sebagai simbol pengetahuan dan intelektual, tetapi juga merupakan simbol status. Bangsawan di Eropa membeli buku dengan halaman yang berlapis emas dan menyusunnya di ruang tamu atau ruang keluarga agar terlihat bahwa tuan rumah tergolong kaum intelektual (Spielvogel, 1998). Menjadi kaum intelektual merupakan syarat agar diterima di kalangan kaum elit. Di perpustakaan, para pustakawan memperlakukan buku dengan berhati-hati, mereka merantai beberapa buku agar tidak hilang.

Aktivitas pustakawan atau profesional informasi dalam mengelola pengetahuan pun diwujudkan ke dalam buku manual AACR, RFID, DDC, Searslist, daftar indeks, dan sebagainya. Tindakan dalam menyusun pengetahuan ke dalam skema klasifikasi menunjukkan cara masyarakat memaknai lingkungannya. DDC (decimal classification dewey) merupakan produk orang Amerika yang memaknai pengetahuan sesuai dengan cara pandang mereka terhadap dunia, sedangkan NDC (nippon decimal classification) yang disusun oleh masyarakat Jepang, diciptakan sesuai dengan cara hidup mereka. Dalam klasifikasi DDC, subjek agama dikelompokkan ke dalam kelas 200, sedangkan dalam NDC, subjek agama tidak ada di dalam skema. Hal tersebut menunjukkan bahwa masyarakat Jepang memaknai agama dalam kehidupan sehari-hari berbeda dengan masyarakat pada umumnya. Demikian pula dengan subjek industri dan perdagangan pada kelompok 600, menunjukkan bahwa masyarakat Jepang menganggap subjek itu penting dalam kehidupan mereka. 
Gambar 1. Skema klasifikasi DDC dan NDC

DDC NDC

000 Komputer, informasi dan referensi 000 Umum umum

100 Filsafat dan psikologi

100 Filsafat

200 Agama

200 Sejarah

300 Ilmu sosial

300 Ilmu sosial

400 Bahasa

400 Sains

500 Sains dan matematika

500 Teknologi

600 Teknologi

700 Kesenian dan rekreasi

600 Industri dan perdagangan

800 Sastra

700 Kesenian

900 Sejarah dan geografi

800 Bahasa

900 Sastra

Secara umum, aktivitas manusia dan pengetahuan atau informasi bukan hanya di perpustakaan, tetapi bisa di mana saja. Apalagi di masa globalisasi ini, dengan dukungan teknologi informasi, pengetahuan dapat diperoleh di mana saja dan kapan saja, tanpa batas ruang dan waktu, sehingga panggung perpustakaan menjadi meluas ke ruang maya. Interaksi antara profesional informasi dan pengguna, serta lingkungannya, akan berbedabeda, sebab setiap individu akan memaknainya secara berbeda-beda.

Sebagai pengelola pengetahuan, profesional informasi memainkan peran strategis, terutama dalam membangun masyarakat pembelajar (learning society atau knowledge sosciety), yang merupakan pembentuk masyarakat informasi. Artinya, profesional informasi memilah dan menentukan pengetahuan yang penting bagi masyarakat; bisa juga menyembunyikan atau mengabaikan pengetahuan yang dianggap membahayakan; atau bahkan bisa memanipulasi pengetahuan tertentu demi kepentingan diri sendiri atau pihak tertentu (Laksmi, 2012). Profesional informasi juga diharapkan dapat menumbuhkan dan meningkatkan minat baca masyarakat, menumbuhkan kebiasaan membaca, atau sebaliknya mematikan minat membaca masyarakat. Dapat disimpulkan bahwa seorang profesional informasi merupakan rajanya 
pengetahuan dalam konteks membangun masyarakat informasi. Di dunia pendidikan, perpustakaan menjadi prasyarat utama untuk mendapatkan nilai akreditasi.

Teori interaksionisme simbolik menempatkan individu sebagai aktor aktif dan pentingnya konsep mengenai diri. Di lingkungan di mana masyarakat cenderung dianggap kental berbudaya lisan, seorang pustakawan seringkali dinilai sebagai penjaga gudang buku, atau seorang arsiparis yang dianggap sebagai pengumpul kertas-kertas dan dokumen arsip, bahkan dianggap sebagai orang buangan (Dahlan, 2013; Pendit, 2008, p. 16). Dengan anggapan seperti itu, sebagian pimpinan di lembaga induk membuat jarak dengan profesional informasi, dengan tidak melibatkannya di dalam banyak kegiatan organisasi, seperti rapat. Citra diri profesional informasi tampak buruk.

Kondisi tersebut diperparah oleh gaya hidup masyarakat yang cenderung hedonis dan konsumtif, serta mengarah pada budaya visual (Ibrahim, 2007, p. 315). Masyarakat lebih banyak bermain dengan gadget, menonton televisi, menghabiskan waktu ke mal dan ke kafe, dan semakin jauh dengan buku. Fakta tersebut memaksa profesional informasi untuk melakukan berbagai upaya, seperti membangun perpustakaan menjadi ruang seperti mal dan kafe. Suasana yang dulu sepi, suram, muram, dan membosankan, sekarang berubah menjadi meriah, terang, ramai, dan menarik. Nama perpustakaan dipercantik dengan mengubahnya ke dalam bahasa Inggris menjadi learning resource center (pusat sumber belajar), clearing house, Library Café, atau dengan menghilangkan kata perpustakaan, menjadi rumah baca, bale pustaka.

\section{Contoh penelitian}

Penerapan teori interaksionisme simbolik pada ilmu perpustakaan dan informasi, khususnya di Indonesia, masih menggunakan metodologis yang standar dalam penelitian kualitatif, belum benar-benar spesifik menerapkan karakter interaksionisme simbolik. Contoh penelitian berikut ini menunjukkan bahwa analisis yang dilakukan terbatas pada tataran 
praktis, yaitu realitas yang teramati. Tujuan penelitian kualitatif adalah memahami makna yang terdapat di balik realitas. Metode yang digunakan menjadi alat untuk membantu menginterpretasi di balik suatu peristiwa, yaitu pemikiran manusia yang terlibat di dalam peristiwa tersebut, dan cara manusia meletakkan makna pada peristiwa terkait. Teori atau metode interaksionisme simbolik memfokuskan penelitian pada perilaku manusia yang dilihat sebagai produk dari hasil interpretasi manusia terhadap dunia di sekitar mereka.

Penelitian ini merupakan tesis Arman Kurniadi, tahun 2014, berjudul Implementasi Berbagi Pengetahuan (Knowledge Sharing) di Perpustakaan Lembaga Penelitian Yayasan Pelangi Indonesia. ${ }^{2}$ Sebagai latar belakang tulisan dinyatakan bahwa proses berbagi pengetahuan pada khususnya dan penerapan manajemen pengetahuan pada umumnya, masih mengalami kendala terutama pada budaya masyarakat yang sulit untuk berbagi pengetahuan. Dalam interaksi di Perpustakaan Yayasan Pelangi Indonesia tersebut, selain peserta dan fasilitator, terdapat kontributor yang terdiri dari para peneliti dan pihak eksternal yang diundang untuk memberikan pengetahuan kepada karyawan Yayasan.

Pertanyaan yang diajukan adalah: 1) bagaimana kontributor, peserta dan fasilitator melakukan berbagi informasi pada perpustakaan lembaga penelitian Yayasan Pelangi Indonesia?; 2) media apa yang digunakan dalam melakukan berbagi informasi pada perpustakaan lembaga penelitian Yayasan Pelangi Indonesia?; 3) bagaimana trust (kepercayaan) antara kontributor dan peserta dalam melakukan berbagi pengetahuan pada perpustakaan lembaga penelitian Yayasan Pelangi Indonesia?

Analisis dimulai dari profil Yayasan Pelangi Indonesia, yaitu sebuah lembaga penelitian independen yang sejak 1990 aktif melakukan penelitian di bidang energi, kehutanan, transportasi, polusi udara, dan perubahan iklim untuk menuju pembangunan yang berkelanjutan. Implementasi berbagi pengetahuan oleh kontributor, peserta dan fasilitator dalam bentuk diskusi,

${ }^{2}$ Diunduh tgl 16 Oktober 2016, dari http://library.fikom.unpad.ac.id/digilib/gdl.php?mod =browse\&op=read\&id=jbptunpadfikom-gdl-armankurni-7278 
yang dilakukan pada 18 Januari 2011 dengan subjek transportasi, 16 Februari 2011 dengan subjek peranan LSM Yayasan Pelangi, dan seterusnya. Media yang digunakan dalam berbagi pengetahuan di Yayasan Pelangi adalah media yang bersifat tatap muka (diskusi dan rapat) dan media online (website, facebook, twitter, dan email pribadi). Sementara itu, trust (kepercayaan) belum berjalan baik, karena masih ada beberapa karyawan yang merasa bahwa berbagi pengetahuan tidak memberikan efek apa pun terhadap kinerja mereka sebagai karyawan. Hal ini terjadi karena diskusi yang sering dilaksanakan hanya menyangkut isu-isu yang terkait dengan penelitian di Yayasan Pelangi; masih adanya karyawan yang merasa bahwa pengetahuan yang dimilikinya tidak memberikan manfaat bagi si penerima, karena si penerima memiliki tingkat pendidikan yang lebih tinggi.

Kesimpulannya adalah bahwa peneliti membagi pengetahuan tacitnya melalui diskusi dan rapat, sedangkan untuk pengetahuan eksplisitnya peneliti lebih sering memberikan dalam bentuk tercetak dan bentuk digital ke Perpustakaan Yayasan Pelangi Indonesia. Karyawan pada bagian lain bisa dikatakan sangat jarang menjadi kontributor pada diskusi atau rapat karena umumnya tema yang diangkat bukan tema yang menjadi keahlian dari karyawan tersebut. Peserta internal menerima pengetahuan dari mengikuti seminar, rapat, dan dari program Infokom, sedangkan peserta eksternal menerima pengetahuan dari website dan dari program Kampanye Pelangi. Fasilitator dalam aktivitas berbagi pengetahuan oleh pustakawan, yang dianggap lebih tepat dalam menggerakkan aktivitas berbagi pengetahuan dan mengelola media berbagi pengetahuan. Saran yang diajukan adalah bahwa untuk menggerakkan kontributor di bagian keuangan dan bagian umum, fasilitator seharusnya membuat sebuah diskusi informal yang membahas tema-tema seputar masalah yang dihadapi dalam menyelesaikan pekerjaan; pimpinan seharusnya menerapkan reward and punishment dalam berbagi pengetahuan; pimpinan harus selalu memantau kegiatan berbagi pengetahuan dan kalau memungkinkan turut serta berpartisipasi dalam kegiatan tersebut, tidak hanya sebatas menjadi kontributor, tetapi juga menjadi peserta. 


\section{Pembahasan contoh penelitian}

Secara kontekstual, permasalahan di dalam penelitian dapat dianalisis dengan metode interaksionisme simbolik, sebab metode tersebut menunjukkan adanya interaksi antara kontributor, peserta, dan fasilitator dalam berbagi informasi. Konteksnya juga mendukung adanya proses interpretif di antara ketiganya, bahwa di perpustakaan Yayasan Pelangi Indonesia yang seharusnya mendiseminasikan pengetahuan tentang lingkungan, para pengelolanya masih sulit berbagi pengetahuan. Antara tujuan organisasi dan para pengelolanya tidak bersinergi.

Sebagai metode yang menekankan proses interaksi manusia melalui penggunaan simbol, pertanyaan penelitian yang diajukan kurang menunjukkan interpretasi atas simbol. Pertanyaan tentang jenis media digunakan dalam melakukan berbagi informasi dapat diajukan apabila media dilihat sebagai simbol. Temuan menunjukkan bahwa mereka menggunakan media tatap muka dan website. Analisis tidak harus berhenti pada jenis media, tetapi bisa dipertajam pada proses yang terjadi dalam media tersebut. Ketika individu saling berbicara berhadap-hadapan, bagaimana sikap ketiga pelaku, mulai dari nada bicara, kata dan kalimat yang dilontarkan, subjek yang dibicarakan, dan sebagainya. Kesimpulan yang menyatakan bahwa di antara mereka tidak ada rasa saling percaya, sebab karyawan merasa lebih rendah di hadapan kontributor, yaitu staf di bagian keuangan, pimpinan, dan peneliti. Para karyawan merasa rendah diri karena tingkat pendidikan yang lebih rendah.

Dalam penelitian kualitatif, umumnya hal pertama yang penting diamati adalah memahami karakteristik para pelakunya. Pemahaman tersebut muncul dari proses interpretif dalam memahami citra diri, kesadaran akan indentitas, yang merupakan produk dari cara orang lain berpikir tentang dirinya. Memahami tindakan individu yang dipahami sebagai hasil proses interpretasinya memaknai situasi merupakan inti dari teori atau metode interaksionisme simbolik. Para pelaku, yaitu kontributor, peserta, dan fasilitator hanya diungkapkan sedikit. Kontributor terdiri dari karyawan 
bagian keuangan dan bagian umum, pimpinan, dan peneliti yang memiliki pendidikan lebih tinggi daripada peserta; peserta terdiri dari karyawan internal dan peserta dari luar organisasi dengan pendidikan yang lebih rendah dari kontributor; sedangkan fasilitator terdiri dari pustakawan yang berperan sebagai perantara antara kontributor dan peserta. Setiap individu membangun citra diri berdasarkan dari hasil cara orang lain berpikir tentang diri individu. Citra diri sangat dipengaruhi oleh reaksi individu yang berhubungan dengannya.

Dalam penelitian tersebut disebutkan bahwa hubungan antara kontributor dengan karyawan dibangun tanpa rasa saling percaya. Pada saat kontributor berbagi informasi kepada peserta, ia membuat penilaian atas kemampuan para peserta. Konsep tentang diri merupakan pijakan untuk diri dalam melakukan tindakan. Peran sebagai peneliti dan dengan gelar kesarjanaan yang dimilikinya memungkinkannya untuk membangun relasi kuasa atas peserta yang bukan peneliti dan yang diasumsikan kurang memahami topik penelitian yang disajikan di dalam pertemuan. Penilaian kontributor tersebut akan mempengaruhi para peserta dalam memandang diri dan kemampuan diri mereka, sehingga perilaku mereka pun menjadi penilaian balik untuk kontributor. Peserta yang sering aktif dan duduk di deretan depan akan dianggap individu yang cerdas, sedangkan peserta yang duduk di deretan belakang dan lebih banyak diam akan dianggap sebagai peserta yang bodoh.

Contoh penelitian di atas masih harus dielaborasi dengan menganalisis perilaku simbolis di antara para pelakunya. Berdasarkan konsep berbagi pengetahuan dapat disimpulkan bahwa latar belakang pendidikan dan kemampuan seseorang merupakan simbol yang digunakan agar dapat diterima dalam kehidupan sosial. Sayangnya, dalam penelitian tersebut tidak disebutkan konsep diri para aktornya secara rinci. Seandainya Arman Kurniadi menjaring data secara lebih rinci, ia dapat menarik kesimpulan lebih tajam. 


\section{Cara melakukan penelitian interaksionisme simbolik}

Cara melakukan penelitian interaksionisme simbolik sama dengan melakukan penelitian kualitatif lainnya. Dalam konteks ilmu perpustakaan dan informasi, penelitian harus dilakukan di dalam konteks yang membungkus manusia dan informasi. Interaksi keduanya harus dikaitkan dengan simbol. Penelitian interaksionisme simbolik dilakukan berdasarkan setting alamiah, sehingga dibutuhkan observasi yang intens. Catatan lapangan harus menguraikan setiap fenomena secara rinci dan spesifik.

Selama proses penelitian berlangsung, peneliti harus memadukan simbol dan interaksi. Prinsip interaksionisme simbolik adalah menganalisis tindakan manusia dalam kaitannya dengan simbol. Simbol yang diamati bukan hanya simbol latar, termasuk dekorasinya, tetapi juga perilaku simbolis yang dilakukan oleh para aktor. Perilaku simbolis seringkali tersamar, sehingga dibutuhkan kepekaan peneliti ketika berada di lapangan. Selain itu, makna simbol harus dipahami sebagai hasil interpretasi subjek atas hubungan sosial dan interpretasinya terhadap lingkungannya.

Peneliti harus dapat mengambil peran orang lain dan berempati dalam posisinya saat itu. Dengan mengambil peran, peneliti dapat memahami tindakan orang tersebut dan memandang dunia dari sudut pandang subjek. Saat melakukan pengambilan peran, peneliti harus dapat membedakan antara konsepsi realitas kehidupan sehari-hari dengan konsepsi ilmiah mengenai realitas tersebut. Realitas bukan seperti apa adanya yang terlihat, tetapi merupakan hasil konstruksi sosial.

Dalam teori interaksionisme simbolik, penggunaaan konsepkonsep mengarahkan peneliti dalam cara berpikir berdasarkan tiga premis Herbert Mead, sehingga dapat menjadi pedoman yang operasional. Sebagai catatan penting yang perlu diperhatikan dalam penelitian interaksionisme simbolik, adalah bahwa makna simbol akan diperoleh secara utuh ketika berada dalam konteks interaksi yang aktif di antara para aktornya. Setiap individu akan menginterpretasi tindakan orang lain, interpretasi tersebut akan bermakna jika individu yang diamati menginterpretasi dan melakukan 
tindakan terhadap individu yang pertama. Jika kedua belah pihak aktif saling menginterpretasi dan melakukan tindakan, maka interaksi tersebut menciptakan makna secara utuh.

Catatan penting lainnya adalah bahwa para aktor dapat mengubah simbol dalam sebuah interaksi sedemikian rupa, sehingga menimbulkan makna yang berbeda dengan makna yang lazim. Perubahan makna simbol dari yang lazim ke makna yang tidak lazim dipengaruhi oleh interpretasi aktor atas situasi yang terjadi saat itu. Tindakan tertentu dipilih karena dipandang tepat dalam konteks di mana individu itu mendefinisikan situasi yang dihadapinya. Oleh karena itu, peneliti harus menggali masalah pemaknaan tersebut kepada individu tersebut. Makna simbol dapat berbeda di tempat dan waktu yang berbeda.

Selain itu, para aktor memanfaatkan simbol melalui permainan bahasa untuk mengungkapkan maksud mereka. Bahasa merupakan simbol identitas, gaya hidup, tempat pertarungan kuasa, penaklukan dan perlawanan, hegemoni dan kontestasi. Bahasa bisa terwujud berupa slogan, kelakar, gosip, bahasa gaul, bahasa SMS atau WA dengan segala atributnya, dan masih banyak lainnya. Penggunaan bahasa merupakan pilihan bagi aktornya untuk mendapatkan interpretasi yang tepat bagi kepentingannya. Oleh karena itu, peneliti juga perlu memahami ragam bahasa tersebut.

\section{Penutup}

Teori dan metode interaksionisme simbolik di bidang ilmu perpustakaan dan informasi perlu dikembangkan lebih jauh. Pengetahuan yang dikonstruksi secara sosial, di masa lalu menjadi makna yang berarti bagi status seseorang, di masa sekarang, menjadi modal intelektual atau modal budaya bagi relasi kuasa di segala aspek kehidupan. Di masa globalisasi ini, di mana interaksi antar individu semakin intens dan semakin bersifat virtual, simbol-simbol yang digunakan juga semakin variatif. Hubungan yang semakin meluas karena komunikasi antar bangsa semakin mudah, makna simbol juga akan semakin memungkinkan untuk berubah. 


\section{Daftar Pustaka}

Bivens-Tatum, Wayne. (September 20, 2013). Review: Jesse Shera, Librarianship, and Information Science. Academic Librarian. On Librarian, Rhetoric, Poetry, History, \& Moral Philosophy. 2/10/2016. http://blogs.princeton.edu/librarian/2013/09/review-jesse-shera

Budd, John M. (Jan, 2003). The Library, Praxis, and Symbolic Power. The Library Quarterly, Vol. 73(1), 19-32. (JSTOR).

Dahlan, Muhidin M. 2013. Politik dan arsip. Koran Tempo. 28 April 2013.

Gorman, G.E dan Clayton, P. 1997. Qualitative research for the information professional: a practical handbook. London: Library Association.

Hall, Stuart, Jessica Evans, and Sean Nixon (eds.). 2013. Representation. Second Edition. London: SAGE Publications Ltd.

Ibrahim, Idi Subandy. 2007. Budaya populer sebagai komunikasi: dinamika popscape dan mediascape di Indonesia kontemporer. Yogyakarta: Jalasutra.

Julien, Heidi \& Jen (J.L) Pecoskie. 2009. Librarians' experiences of the teaching role: Grounded in campus relationships. Library \& Information Science Research, 31(2009), pp. 149-154. 10 October 2016. http:// home.ubalt.edu/ub78145/My\%20Library/storage/SH4P7XDX/ Julien_Librarians'-experiences-of-the-teaching-role-Grounded-incampus-relationships_2009.pdf

Kurniadi, Arman. 2014. Implementasi Berbagi Pengetahuan (Knowledge Sharing) di Perpustakaan Lembaga Penelitian Yayasan Pelangi Indonesia. Diunduh tanggal 2 Oktober 2016, dari http://www. slideshare.net/ArmanKurniadi/sidang-tesis.

Laksmi. (2012). Interaksi, interpretasi, dan makna: pengantar analisis mikro untuk penelitian di bidang ilmu informasi dan ilmu terapan lainnya. Bandung: Karya Putra Darwati.

. (2015). Pendekatan kualitatif dalam mata ajar metolit di Prodi Ilmu Perpustakaan dan Informasi, DIPI, FIB UI. Lokakarya Penelitian Ilmu Perpustakaan, Kearsipan, dan Informasi, di FIB, Depok, Selasa, 17 
Maret 2015.

Pendit, Putu Laxman. (ed.). 2009. Merajut makna: penelitian kualitatifbidang perpustakaan dan informasi. Jakarta: Cita karyakarsa Mandiri.

-----. 2008. Kepustakawanan Indonesia, dari mana, ke mana? Dalam FA. Wiranto (ed.). Perpustakaan dalam dinamika pendidikan dan kemasyarakatan. Dilengkapi dengan UU no. 43 Tahun 2007 tentang Perpustakaan. Seri Pengembangan Perpustakaan No. 5.

Poerwandari, Kristi. (2005). Pendekatan kualitatif untuk penelitian perilaku manusia. Depok: LPSP3.

Powell, R. (1997). Basic Research methods for librarians. $3^{\text {rd }}$ ed. Greenwich: Ablex.

Spielvogel, Jackson J. (1998). World history: the human Odyssey. Cincinnati, AS: West Educational Publishing.

Veinot, Tiffany C. \& Williams, Kate. (May, 2012). Following the "Community"Thread From Sociology to Information Behavior and Informatics: Uncovering Theoretical Continuities and Research Opportunities. Journal of the American Society for Information Science and Technology, 63(5), 847-864. DOI: 10.1002/asi.21653. Wilson, T.D. Sociological aspects of information science. International Forum on Information and Documentation, 6(2), 1981, 13-18. Diunduh pada 2 Oktober 2016, di http://www.informationr.net/tdw/publ/papers/ socasp81.html

Wright, H. Curtis. (Spring, 1986). The symbol and its referent: an issue for library education. Library Trends, 34(4), 729-776. 